\author{
A.P. Kireyev ${ }^{1}$ \\ International Monetary Fund, Washington, D.C., USA; \\ Moscow School of Economics, Moscow, Russia
}

A.V. Leonidov

P.N. Lebedev Physical Institute, Russian Academy of Sciences;

Moscow Institute of Physics and Technology, Moscow, Russia

\title{
A Network Model of Multilateral Equilibrium Exchange Rates ${ }^{2}$
}

\begin{abstract}
The objective of the paper is to propose a new network model of multilateral equilibrium exchange rates based on network theory. The model introduces a topological component into the exchange rate analysis, consistently taking into account simultaneous higher-order interactions among all currencies. The article argues that the evolution of nominal exchange rates can be modeled on a network, where the nodes represent individual currencies and the links among them represent weighted returns on a hypothetical investment in each currency. For the purposes of this article, a multilateral exchange rate network is represented by multilateral dependent changes in bilateral exchange rates. The currency demand indicator (CDI), an elementary cell of the network model, is defined as weighted log-returns on each currency. The CDI provides a useful proxy for demand for each currency from other currencies and reflects all underlying balance of payments flows. The model identifies the stationary position of the exchange rate network, i.e. the episodes of minimal temporal variety of the CDI, when weighted returns on the links are close to zero. The stationary position of the exchange rate network points to the equilibrium levels of bilateral exchange rates for each currency pair. The model applies mainly to currencies with floating exchange rate regimes, although useful information can also be obtained for currencies with pegged exchange rates. For illustration, the model is applied to bilateral daily 1995-2016 exchange rates among130 currencies sourced from the Thomson Reuters Datastream.
\end{abstract}

Keywords: exchange rate, networks, equilibrium, trade.

JEL Classification: C45, F14, F41, F42, F47.

DOI: $10.31737 / 2221-2264-2019-41-1-1$

\section{Introduction}

Increased volatility of exchange rates has become a focal point in policy debates. Policymakers have raised concerns about excessive exchange rate volatility arising from advanced economy stimulus, the decline in commodity prices, the slowdown in China, geopolitical tensions, as well as the other factors yet to be understood. Further risks arise from the US monetary policy normalization, which may spill over through the exchange rates on the rest of the world. These concerns call for new models of equilibrium exchange rates, which could be used for policy analysis, monitoring, and implementation.

The objective of the paper is to build a model of multilateral equilibrium exchange rates for policy setting and implementation. This paper draws

\footnotetext{
${ }^{1}$ The views are those of the author and do not necessarily represent the views of the IMF, its Executive Board, or IMF management.

${ }^{2}$ The authors are grateful to D. Cerdiero, V. Chensavasdijal, L. Cubeddu, C. Jarvis, M. Kaufman, E. Kitsios, C. Kramer, R. Lama, C. Pattillo, R. Zandamela for helpful comments. Research assistance by D. Khlynova and Y. Ye is gratefully acknowledged. Any remaining errors are the authors'.
} 
on our earlier research on network macroeconomics, in particular related to the spillovers from nominal shocks in static and dynamic contexts (Kireyev, Leonidov, 2015, 2016). The model proposed in this paper introduces a topological component into the exchange rate analysis, consistently taking into account higher-order interactions between all currencies at the same time. In this paper we propose a currency demand indicator; construct a time-dependent multilateral exchange rate network; find its dynamically stationary position and identify multilateral equilibrium levels of exchange rates.

The objective of the model is to propose a methodology for assessing the deviations of the observed bilateral exchange rates from their multilateral stationary levels, which can be interpreted as their over- or undervaluation. The model is not designed to assess exchange rate volatility or forecast exchange rate evolution. Rather, it suggests a new concept of multilateral equilibrium exchange rates, which can be used to guide macroeconomic policies. The model can be used in policy debate by pointing at the multilateral equilibrium's exchange rate values during the periods of a relative stability of the exchange rates network. For illustration, the model is applied to daily 1995-2016 exchange rates from the Thomson Reuters Datastream.

Multilateral equilibrium exchange rates differ from fundamentally equilibrium exchange rates. First, the concepts of multilateral equilibrium and fundamental equilibrium exchange rates are defined differently. For the purposes of this paper, an equilibrium exchange rate is defined as the exchange rate of a currency that remains relatively stable during a prolonged period of time. Concomitantly, the multilateral equilibrium exchange rates are defined as the periods when all nominal bilateral exchange rates remain simultaneously relatively stable during a prolonged period of time. Meanwhile, the fundamental equilibrium exchange rates are defined in real effective terms relative to a set of a country's own fundamentals, also taken relative to the fundamentals of its economic partners. In this approach, the exchange rate is deemed to be consistent with the fundamentals and desirable policies if it leads the net external asset position to evolve in a manner consistent with the economy's structure, fundamentals, and appropriate policies (IMF, 2015). Second, the reference points for assessment are different. The multilateral equilibrium exchange rates of currencies are assessed relative to each other, whereas the fundamental equilibrium exchange rate of a currency is assessed relative to a set of fundamental macroeconomic indicators. Third, from an economic point of view, high volatility of multilateral exchange rates should be associated with disequilibria, whereas high volatility of fundamental exchange rates should not. In fact, shocks to country fundamentals could trigger volatility in the currency rates that is desirable from the viewpoint of external adjustment and can be seen as a useful policy response.

Only a few earlier studies touched on the issue of equilibrium exchange rates in a network context. While a substantial body of literature that has emerged in the past few years that applies network theory to the 
financial sector and macroeconomic problems (Acemoglu, Akcigit, Kerr, 2015), attempts to model exchange rates in a network context have been limited. The authors (Fracasso, Schiavo, 2009), for example, used network analysis to find out whether a realignment of exchange rates could help redress international imbalances. (Sinha, Kovur, 2013) reconstructed the network structure of the world currency market and looked at the cross-correlations between exchange rates in the network context. (Serrano, Boguñá, Vespignani, 2007) suggested the concept of a dominant flow, which allows the unraveling of local and global high-flux pathways that define the backbone of international payment flows in different currencies. Recent developments in complex network theory can also be considered as a useful background for the proposed model of equilibrium exchange rates. Specifically, (Kivelä et al., 2014) standardized key concept and notation for multilayer networks. (Squartini, Garlaschelli, 2014) introduced the concept of quasiequilibrium graph ensembles and applied it to the international trade network; and (Caschili, Medda, Wilson, 2015) suggested an early model for a multilayer international economic network.

The analytics of this paper are inspired by network analysis in application to financial markets and risk management. In particular, (Sornette, 2002) proposed the concept of catastrophic events, i.e., statistical outliers with different properties than the rest of the population, that result from mechanisms of critical cascades. He described a unifying approach for modeling and predicting these catastrophic events. The authors (Bouchaud, Potters, 2003) suggested the concept of variety, the standard deviation of returns over the population of financial assets at a given date, which measures instantaneous heterogeneity of shocks. This indicator can be used in addition to the traditional temporal volatility of market returns. Finally, (Heiberger, 2014) introduced a general model of networks' stationarity in application to financial networks, which can be stable in terms of the size, the density of connections, and the average interaction strength; and formalized the corresponding stability condition as well. Some of these ideas are embedded in our model.

This paper contributes to the existing literature in several areas:

i) it develops a computable network model of multilateral equilibrium exchange rates;

ii) it proposes the currency demand indicator (CDI), which can be used to assess demand for each currency across all balance of payments flows;

iii) it suggests the concept of the multilateral exchange rate network stationarity which points at the equilibrium levels of bilateral exchange rates;

iv) it illustrates the concept of multilateral equilibrium exchange rates based on daily 2005-2016 exchange rate dynamics. Potentially, the proposed network model of multilateral equilibrium exchange rates could allow for the estimation of the magnitude of under-and 
overvaluation of individual currencies relative to their multilateral equilibrium rates.

To model exchange rates on a network, the paper proceeds as follows. Section I proposes a network model of exchange rates. Section II discusses the empirics of exchange rates in a network context. Section III presents conclusions.

\section{Analytics}

\section{Exchange Rate Network}

Exchange rates reflect the balance between supply and demand for each currency for payments across all balance of payment flows. The balance of payments (BoP) itself can be viewed as a multilayer network and a closed system as it reflects all payments within over a hundred layers, such as trade, services, remittances, dividends, foreign direct and portfolio investment, credit, reserve assets etc. If the BoP is viewed as a multilayer network, then each node of this network can belong to any of its layers, and the links can encompass pair-wise connections between all possible combinations of nodes and layers. Therefore, a multilayer BoP network can have any number $d$ of dimensions and a sequence $L=\left\{L_{\alpha}\right\}_{\alpha=1}^{d}$ of elementary layers, such that there is one set of elementary layers $L_{\alpha}$ for each dimension $\alpha$ (Kivelä, 2014). All possible types of links that can occur between any pair of nodelayers are included in a multilayer BoP network.

Exchange rates can be presented as a network. An elementary exchange rate network would consist of nodes and links among them. Each currency would be considered as a separate node. The links among the nodes (currencies) would be represented by weighted log-returns on a hypothetical investment in each currency. Such returns can be positive or negative and can be obtained if a hypothetical investor buys a selected currency and its exchange rate to other currencies moves. Therefore, the weighted changes in exchange rates, rather than the exchange rates themselves, are shown as the links of the network.

Such an exchange rate network can be described as a directed, weighted, incomplete, and asymmetric graph. The graph is directed because the changes in the exchange rates embedded into the log-returns on the links explicitly indicate the direction of the BoP flow between currencies during the selected time period. The graph is weighted because all the links reflect some value of payment that is different for each currency pair. The graph is incomplete because not all the currencies are connected with each other through a direct exchange rate and traded directly, as many are quoted through a cross-rate to the US dollar. Finally, the graph is asymmetric because the value of implicit outflows on links for all currency nodes differs from the value of implicit inflows.

This concept of an exchange rate network is fundamentally different from those suggested so far in the literature. For example, (Fracasso, Schiavo, 2009) constructed an exchange rate network by putting on the links 
the exchange rates weighted by related trade flows, i.e., effective exchange rates. (Sinha, Kovur, 2013) built an exchange rate network with the links representing correlation between log-returns for each pair of currencies. (Phillips et al., 2013) proposed an external balance assessment methodology, which ensures multilateral consistency by adjusting each exchange rate residual by the global weighted average of residuals. (Matesanz, Ortega, 2014) used the Pearson correlation and phase synchronous coefficients as links. (Qiao, Xia, 2015) turned correlation coefficients into distances between each currency pair nodes and applied them to the links among the nodes. Finally, (Wang, Xie, 2016) constructed the exchange rate network with tail dependencies as the links among currencies. In the suggested exchange rate network, the links between the currency nodes are represented by weighted log-returns on each currency pair. The nodes themselves reflect the multilateral demand for each currency from all the other currencies simultaneously.

The representation of the network a graph of weighted log-return flows allows to avoid the problems of the base currency. The problem is that for statistical purposes all currencies are usually quoted to the USD. However, in reality on the global foreign exchange market, currencies are quoted to each other and therefore do not have a common denominator, the base currency. The selection of the base currency can influence research outcomes as the changes of its rate would disproportionally affect the exchange rates for all other currencies that are priced to the unit of the selected base currency. In previous research on currency networks, several options have been suggested for the selection of the base currency e.g. USD, SDR, any minor currency, and prices for precious metals (Kwapień et al., 2009). Nevertheless, any arbitrary selection of the base currency has posed major problems, if the links are represented by any form of correlation between exchange rates in a network. Such networks were found to exhibit different properties depending on the choice of the base currency. Such exchange rate networks would be strongly influenced by the evolution of the base currency and may lead to ambiguous results reflecting mainly the judgment on the selection of the base currency.

The proposed network model allows avoiding the problem of the base currency selection altogether, as the links represent the observed changes rather than the evaluated correlations. The model does not rely on correlations among exchange rates, but rather on an indirect representation of BoP flows through log-returns. For example, if the rate of USD relative to EUR increases during a given period, it means that there is an underlying net BoP flow in the direction to USD from EUR. On a graph, it will be reflected by a link (an arrow) from the EUR node to the USD node scaled by the weight of the EUR/USD pair in the global foreign exchange turnover. Such indirect representation of BoP flows is useful for the analysis of exchange rates as bilateral flow statistics are still insufficiently developed and do not exist for most bilateral flows other than trade payments and for- 
eign direct and portfolio investment. The statistics on bilateral payments is not available beyond bilateral trade payments (UN Comtrade). On bilateral financial flows, the IMF's Coordinated Direct and Portfolio Investment surveys (IMF, 2016) are the main source, but the data on bilateral investment flows are available only for a limited number of countries.

To summarize, the exchange rate network consists of weighted nodes and weighted links (Figure 1). The nodes are represented by individual currencies (not countries) and are weighted by the multilateral demand for each currency from all other currencies. The links are represented by weighted log-returns on each currency and indirectly reflect all underlying balance of payments flows. The appreciation of the exchange rate of a currency is represented by an inflow into its node. The depreciation of the exchange rate of a currency is represented by an outflow from its node.

The topology of the exchange rate network evolves constantly. Not all the currency pairs are traded every day. Therefore, the composition of links changes on a daily basis. Furthermore, bilateral exchange rates fluctuate continuously and change the topology of the network. For example, in special time periods of USD appreciation, the network would show substantial inflows in the direction of the USD node from most, but not necessarily all, of the nodes. Analogously, in time of USD depreciation, there should be observable outflows from the USD node to other nodes. Such

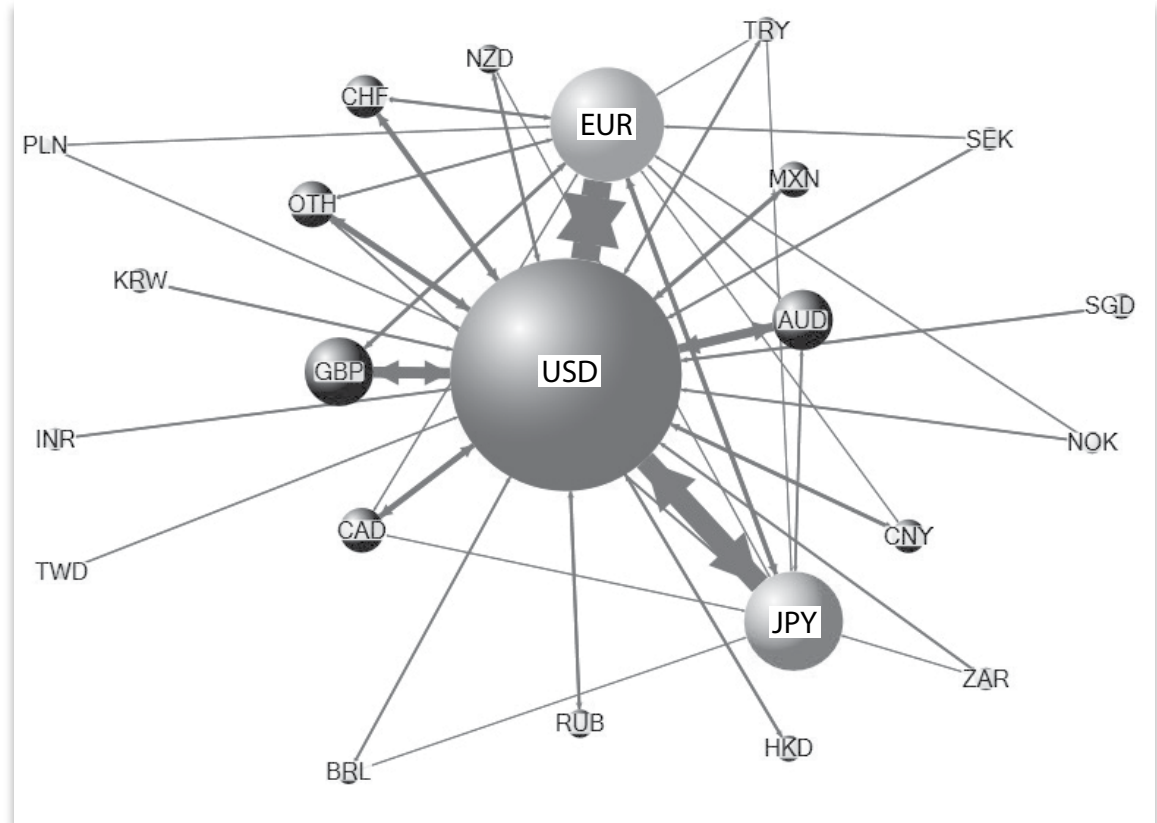

Figure 1

Exchange rate network

Source: Authors' concept. The nodes are weighted by the share of the currency in the international currency turnover (BIS, 2013). The links reflect weighted log-returns between each pair of currencies and the approximate demand for each currency from other currencies. 
complex dynamics can be observed for most other currencies as well. For example, GBP can appreciate relative to USD but depreciate relative to EUR. In this case, the network will show an inflow to the GBP node from the USD node, but an outflow from GBP to EUR. With large exchange rate volatility, the overall multilateral exchange rate network can be considered inherently not stationary. However, there should be episodes of relatively low overall exchange network volatility, which can be viewed as the episodes of the network stationarity.

A stationary position of the exchange rate network as a whole would point at the equilibrium levels of all bilateral exchange rates. The question is whether the temporal evolution of the exchange rate network is dynamically stationary, i.e., whether the system undergoes smooth structural changes controlled by a few driving parameters. When this is the case, the behavior of the exchange rate network is largely controllable and predictable in terms of the dynamics of these parameters. On the other hand, the lack of stationarity may result in abrupt transitions and uncontrollable dynamics. Stationarity does not mean constancy of the numerical values of exchange rates. It rather means that the network's evolution is systematically driven by the dynamics of the chosen constraints and by the processes driving these constraints.

Finally, during a stationary network episode, the multilateral equilibrium bilateral exchange rate for each currency pair can be found. The deviations from these levels may be viewed as temporary and unsustainable, which should disappear in the medium term. The difference between the multilateral equilibrium bilateral exchange rates and the observed exchange rates could be interpreted as exchange rate misalignment.

\section{Model}

The balance of payment flows among currency nodes can be indirectly measured by log-returns for individual currencies. The concept of log-returns is standard in finance, where it is often used to measure profit on investment (Brooks, 2014; Bouchaud, Potters, 2003). In the case of the exchange rate network, log-returns would measure the profit or loss on a hypothetical investment in an individual currency as a result of the shifts of its exchange rate relative to all other currencies in a given time period. Therefore, $\log$-return $\eta_{i j}$ on an investment in currency $i$ from currency $j$ can be defined as logarithm of the change in the exchange rate $r_{i j}$ of currency $i$ with respect to currency $j$

$$
\eta_{i j}(t)=\ln \frac{r_{i j}(t)}{r_{i j}(t-1)} .
$$

The exchange rate network consists of multiple currency pairs linked either directly or through an intermediate currency. It is heavily dominated by a few major traded currency pairs such as EUR/USD, USD/JPY, GBP/USD, etc. To weigh the log-returns, the currency pairs' weights $\lambda_{i j}$ can 
be defined as the share of each currency pair $i \leftrightarrow j$ in the global foreign exchange market turnover. For major currency pairs the weights are known from Bank of International Settlements (BIS, 2013) statistics. The weights of the remaining currency pairs, which represent less than two percent of the exchange market turnover, can be reconstructed under the assumptions that they are distributed evenly across the network. For example, the GBP/ JPY pair is included in the "other" currency pairs' category in BIS statistics. With each currency included on both sides of a pair, the total weights of all currency pairs add up to 200 percent.

The links in the exchange rate network are described by pair flows. The value of a logarithmic flow along the chosen link $i \leftrightarrow j$ is an absolute value of the weighted logarithmic return on this link

$$
\lambda_{i j}\left|\eta_{i j}\right| \text {. }
$$

The weighted exchange rate network or its subset can be characterized by

$$
\sum_{i j} \lambda_{i j}\left|\eta_{i j}\right|
$$

where the sum is over all the links under consideration.

To approximate the value of flows among all currency nodes in a network, the links among them need to be weighted. Therefore, the bilateral currency demand indicator $\varphi_{i j}$ for currency $i$ from each currency $j$ can be defined as a weighted log-return for investment in currency $i$ given the weight of each currency pair in the global foreign exchange market

$$
\varphi_{i j}(t)=\lambda_{i j} \eta_{i j} \text {. }
$$

However, demand for a particular currency is multilateral, not bilateral. It is presented from all the other currencies (Figure 2). Therefore, multilateral currency demand indicator $\chi_{i}$ (CDI) for currency $i$ from all other currencies $(j=1, \ldots, N)$ simultaneously can be defined as a sum of weighted log-returns for investment in currency $i$ from the other currencies given the weight of each currency pair in the global foreign exchange market

$$
\chi_{i}(t)=\sum_{j=1}^{N} \lambda_{i j} \eta_{i j}
$$

To the best of our knowledge, the CDI was not proposed in the earlier literature.

Based on the above definitions, an exchange rate network can be constructed as follows. The exchange rate network is defined as a symmetrical, weighted, and directed graph. The nodes represent the CDI $\chi_{i}(t)$, i.e. the multilateral currency demand for each currency from all other currencies in the network. The

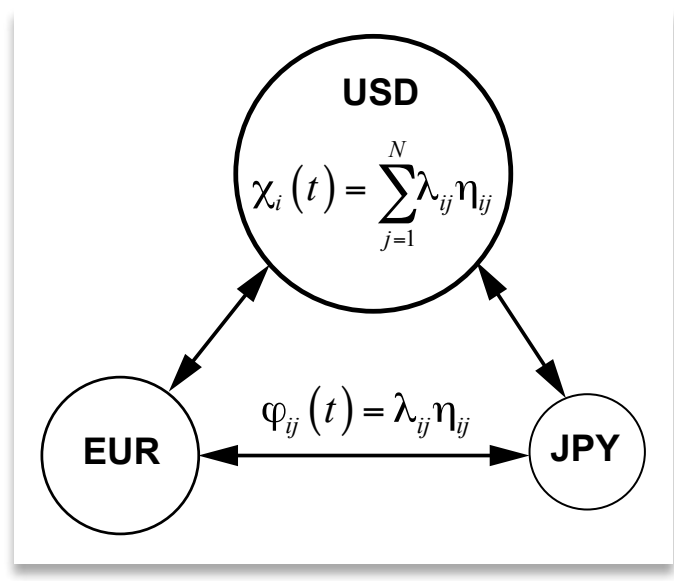

Figure 2

Currency demand indicator

Source: Authors' concept. 
size of the nodes is proportional to the average CDI. The links represent $\varphi_{i j}(t)$, i.e., the bilateral currency demand. The width of the links is scaled by the share of the log-return on each currency pair in the global currency market. The arrow indicates the direction of the net demand for each currency in a given day. If $\varphi_{i j}(t)>0$, there is excess demand for currency $i$ from currency $j$, i.e., there was an unobserved financial inflow $(i \leftarrow j)$ reflected in the appreciation of currency $i$. Symmetrically, if $\varphi_{i j}(t)<0$, there is an unobserved outflow from currency $i$ to currency $j,(i \rightarrow j)$, leading to reduced demand for currency $i$, which depreciates as a result.

The degree of stationarity of the exchange rate network can be evaluated across time and across currencies based on the CDI. Across time $(t)$ temporal volatility $(\mu)$ of the CDI $(\chi)$ can be calculated as a standard deviation in the multilateral demand for each currency $(i)$ during the selected period of observations $(T)$

where

$$
\mu_{\chi}^{i}=\sqrt{\frac{1}{T} \sum_{t=0}^{T}\left(\chi^{i}(t)-\bar{\chi}^{i}\right)^{2}},
$$

$$
\bar{\chi}^{i}=\frac{1}{T} \sum_{t=0}^{T} \chi^{i}(t)
$$

is the accumulated temporal volatility of the CDI for a given time period. Temporal volatility measures the degree of stationarity of the exchange rate network along time.

To evaluate the degree of stationarity of the exchange rate network across currencies, sectional variety $(v)$ of the CDI $(\chi)$ can be calculated. It is defined as a standard deviation of currency demand across all $N$ currencies on a given day (Bouchaud, Potters, 2003)

$$
v_{\chi}(t)=\sqrt{\frac{1}{N} \sum_{i=0}^{N}\left(\chi^{i}(t)-\bar{\chi}\right)^{2}},
$$

where

$$
\bar{\chi}(t)=\frac{1}{N} \sum_{i=0}^{N} \chi^{i}(t)=0 .
$$

The sum of sectional CDIs is equal to zero by definition, because the global foreign exchange market clears daily, as the overall currency demand is met by currency supply. Sectional variety measures daily pulsation of the exchange rate network at a point in time.

Sectional variety is sufficient to evaluate network stationarity. A stationary exchange rate network can be defined as the periods when the temporal volatility and sectional variety are simultaneously minimal. However, in the above definition, sectional variety already embeds temporal volatility as both sectional variety $v(t)$ and temporal volatility $\mu(t)$ of CDI $\chi$ are timedependent. Therefore, the periods of minimal sectional variety $v(t)$ of $\chi$ in fact represent the periods of the exchange rate network stationarity. The stationary exchange rate network can be defined as the network with the 
minimal CDI variety. In this approach, network stationarity is a static concept as it is defined relative to the mean of each CDI, not to its trend, and as weighted increments in long-returns around the mean that are close to zero $^{3}$. This stationary position of the exchange rate network would point at the multilateral equilibrium levels of bilateral exchange rates.

The stationary episodes exchange rate network can be empirically found using two thresholds. Threshold 1 (floor) can be defined as the minimum variety of the CDI plus one standard deviation. The deviation from the threshold would be calculated as a variety minus the threshold value for each date. All negative values can be considered as the dates of the lowest currency demand variety across the whole network relative to the selected threshold, the lowest cross-sectional variety of currency demand. Next, monthly periods of the lowest CDI variety can be found by applying a 22-day moving average window (an average work period in one month, 2,607 days / 120 months) to the number of days with negative deviations from the threshold. Threshold 2 can be defined as 80 percent of the lowest variety days within each 22-day window, i.e., during each 22-day period there should be at least 18 days with the lowest variety of the CDI. The application of these two thresholds would allow finding the periods of multilateral equilibrium exchange rates and the corresponding nominal values $^{4}$.

The model rests of a number of assumptions. It assumes that the exchange rates already reflect all fundamental factors affecting each currency, exchange rate movements represent underlying balance of payments flows for payments in different currencies, and the exchange rate reflects the balance of global demand and supply of a particular currency. Also, this balance of demand and supply of currencies is delinked from countries of their issuances. For example, demand for USD may be presented by traders in Saudi Arabia and China, which settle their bilateral trade accounts in USD, although neither of them issues USD. Finally, the equilibrium is assumed to be static, as the model finds the minimal value of the CDI and the periods, when it does not fluctuate much around its own mean.

The model can potentially have important policy implications. First, it can be used for exchange rate assessment, as it allows finding ex-post the periods of multilateral equilibrium exchange rates and calculating the deviation of the observed bilateral exchange rated from their latest multilateral equilibrium levels, which may not be immediately evident in either bilateral exchange rate moves of pressure on reserves. This would help detect potential over- and undervaluation of individual currencies and provide policy recommendations. Second, the model can help design early warning indicators of possible currency crises as the temporal currency demand volatility and sectional currency variety, and therefore the overall exchange rate instability tends to increase before crises.

\footnotetext{
${ }^{3}$ The authors (Harvey, Stock, 1988) decompose series into stationary part (drift), deterministic and stochastic trends. It is useful to determine stationarity of a single time series, but it is not applicable to a network.

${ }^{4}$ Structural breaks can be also identified with models comparing multivariate mean rates during various time slots. The task of such models is structural break identification (Zivot, Andrews, 2002).
} 


\section{Empirics}

DATA

Data requirements for the model are minimal. As the main input, the model uses daily exchanges rates for 130 currencies with respect to the US dollar in units of national currency per one USD for 2005-2016 (Annex 1). As an additional input, the paper uses BIS weights of currency pairs in the global foreign exchange turnover. Such weights are available for 21 currency pairs involving USD, for 15 currency pairs involving EUR, and nine currency pairs involving JPY (Annex 2). The weights on bilateral flows can be presented in a form of an adjacency matrix (Table 1). For example, the weight of the EUR/USD pair in the global currency turnover is 24.1 percent. As all currency pairs are included in the matrix twice, their weights add to 200 .

The matrix shows foreign exchange turnover by currency pair. The shares of identified currency pairs in the matrix add up to 197.5; the remaining 2.5 percent is assumed to be distributed equally among all other currencies, not included in this matrix. Because two currencies are involved in each transaction, the sum of the percentage shares of individual currencies totals 200 percent instead of 100 percent.

The proposed currency network is capable to capture stability of the exchange rates of all currencies in the sample. Although the weights are heavily centered on reserve currencies, all other currencies are also included in the network but with much lower weights. Their weights reflect the relative share of trade in these currency pairs in the global market. Some important currency pairs, such as JPY / GBP, have negligible weight in the matrix as, according to (BIS, 2013); they are not traded directly but rather are exchanged through the USD as an intermediate currency. When a Japanese trader buys USD with the view to ultimately buy GBP, he still initially creates demand for USD as a carry currency, which for the purposes of the model is identical to the direct demand for USD from any other currency.

The exchange rates of individual currencies reflect multiple factors, in addition to the fundamentals of the issuing countries. The macroeconomic policy of the countries of issuance, even in relation to all other countries, is only one of many factors that influence the exchange rate of its currency. For example, demand for USD may be completely detached from the need to pay for imports or reimburse liabilities to the United States. Oil and many other commodities are traded mainly for USD. Therefore, demand and supply of USD, and therefore its exchange rate, can be affected by any country that buys or sells goods or services in USD, invests in USDdenominated assets or settles USD-denominated liabilities. A similar assumption can be taken for any other currency, although on a smaller scale.

The CDI matrix was constructed based on daily log-returns for each currency pair and the matrix of their weights. This adjacency matrix of 130x130 dimensions reflects the weight of bilateral currency pairs in the global currency turnover. This matrix allows starting from bilateral log- 
\begin{tabular}{|l|l|l|l|l|l|l|l|l|l|l|l|l|l|l|l|l|l|l|l|l|l|l|l|l|l|}
\hline & 0 & 0 & $\infty$ & 0 & 0 & 0 & 0 & 0 & 0 & 0 & 0 & 0 & 0 & 0 & 0 & 0 & 0 & 0 & 0 & 0 & 0 & 0 & 0 & 0 & 0 \\
\hline 0 & $f$ & $-i$ & 0 & 0 & 0 & 0 & 0 & 0 & 0 & 0 & 0 & 0 & 0 & 0 & 0 & 0 & 0 & 0 & 0 & 0 & 0 & 0 & 0 & 0 & 0 \\
\hline
\end{tabular}

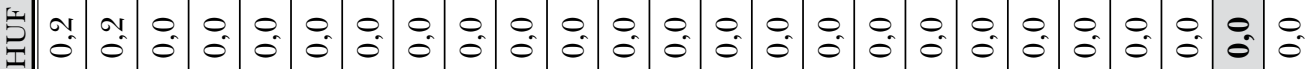

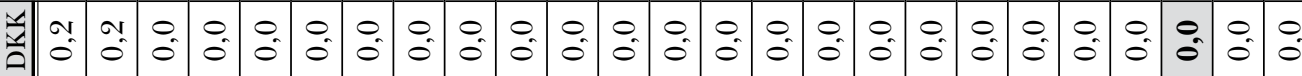
\begin{tabular}{|llllllllllllllllllllllllllllll}
$H$ & 0 & 0 & 0 & 0 & 0 & 0 & 0 & 0 & 0 & 0 & 0 & 0 & 0 & 0 & 0 & 0 & 0 & 0 & 0 & 0 & 0 & 0 & 0 & 0 \\
0 & 0 & 0 & 0 & 0 & 0 & 0 & 0 & 0 & 0 & 0 & 0 & 0 & 0 & 0 & 0 & 0 & 0 & 0 & 0 & 0 & 0 & 0 & 0 & 0
\end{tabular} $\begin{array}{llllllllllllllllllllllllllllll}Z & H & n & 0 & 0 & 0 & 0 & 0 & 0 & 0 & 0 & 0 & 0 & 0 & 0 & 0 & 0 & 0 & 0 & 0 & 0 & 0 & 0 & 0 & 0 & 0 \\ 0 & 0 & 0 & 0 & 0 & 0 & 0 & 0 & 0 & 0 & 0 & 0 & 0 & 0 & 0 & 0 & 0 & 0 & 0 & 0 & 0 & 0 & 0 & 0 & 0\end{array}$

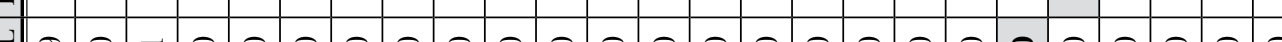

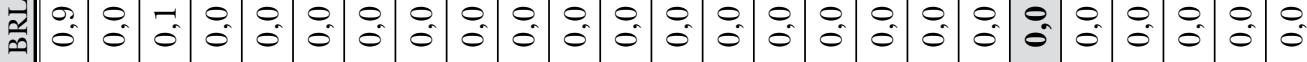
\begin{tabular}{l|l|lllllllllllllllllllllllllll}
\hline & 0 & $H$ & 0 & 0 & 0 & 0 & 0 & 0 & 0 & 0 & 0 & 0 & 0 & 0 & 0 & 0 & 0 & 0 & 0 & 0 & 0 & 0 & 0 & 0 & 0 \\
0 & 0 & 0 & 0 & 0 & 0 & 0 & 0 & 0 & 0 & 0 & 0 & 0 & 0 & 0 & 0 & 0 & 0 & 0 & 0 & 0 & 0 & 0 & 0 & 0
\end{tabular}

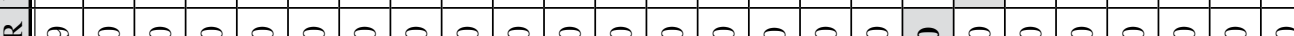

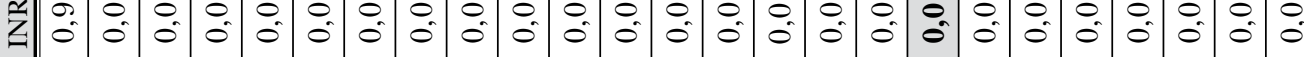
$\because 0 \begin{array}{lllllllllllllllllllllll}0 & 0 & 0 & 0 & 0 & 0 & 0 & 0 & 0 & 0 & 0 & 0 & 0 & 0 & 0 & 0 & 0 & 0 & 0 & 0 & 0 & 0 & 0\end{array}$

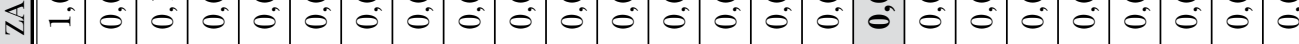

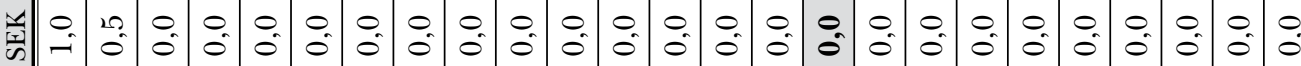
$=$\begin{tabular}{lllllllllllllll|l|l|l|l|l|l|l|l|l|l|l|l|}
3 & 0 & 0 & 0 & 0 & 0 & 0 & 0 & 0 & 0 & 0 & 0 & 0 & 0 & 0 & 0 & 0 & 0 & 0 & 0 & 0 & 0 & 0 & 0 & 0 \\
0 & 0 & 0 & 0 & 0 & 0 & 0 & 0 & 0 & 0 & 0 & 0 & 0 & 0 & 0 & 0 & 0 & 0 & 0 & 0 & 0 & 0 & 0 & 0
\end{tabular}

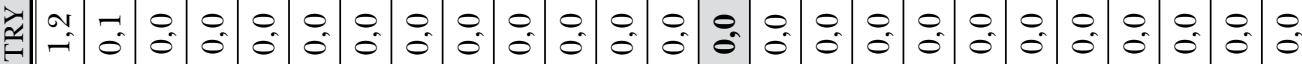

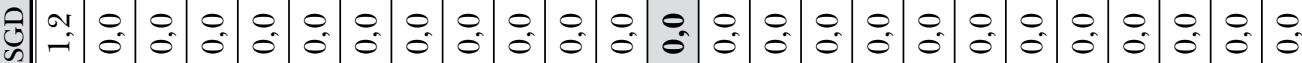

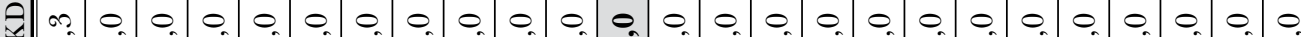

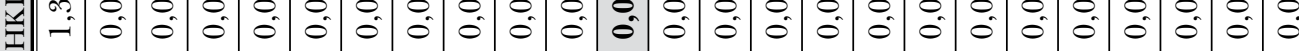

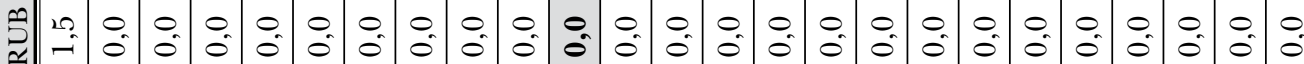

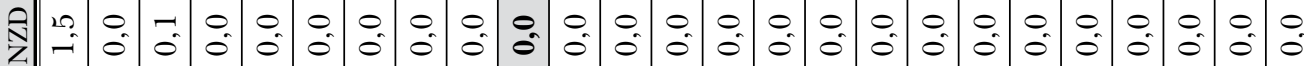

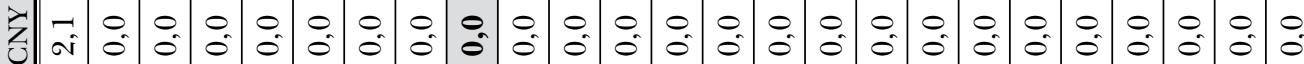

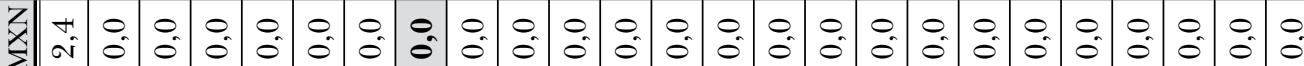

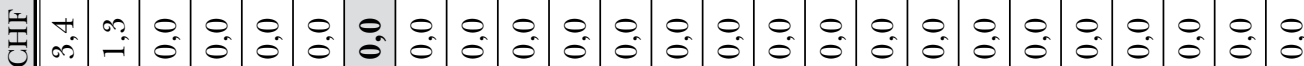
$\bar{\Xi}$

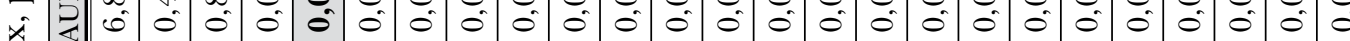

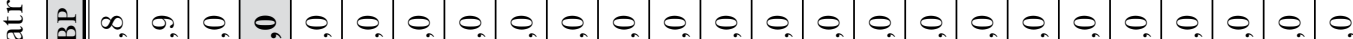

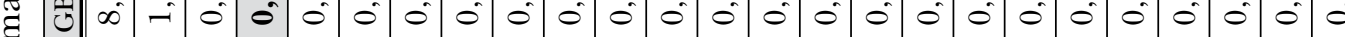

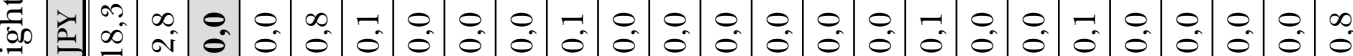

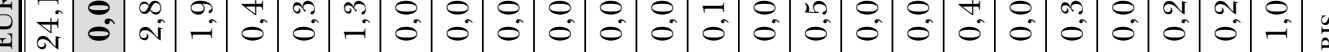

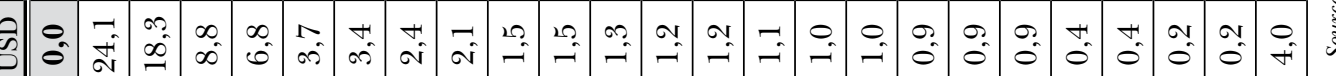

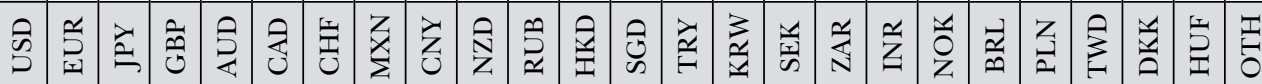


returns (eq. 1) to calculate weighted log returns (eq. 3), and ultimately - the multilateral CDI (eq. 5) for each currency. This indicator shows weighted demand for each currency from all other currencies in the international exchange rate network.

\section{Results}

To identify the periods of the exchange rate network stationarity, both thresholds have been defined using daily CDI for 2005-2016. Threshold 1 (2.66E-04) was calculated as the minimum variety of the CDI during this period (2.0295E-05) plus one standard deviation (2.46E-04). The deviation from the threshold is the observed variety for daily CDI minus the threshold value for each date. In about a half of 2.610 daily observations, the differences between the observed CDI variety and the threshold were negative. These negative values point at the dates of the lowest CDI variety across the whole network relative to the selected threshold. To establish the period of relative exchange rate network stationarity, relatively prolonged periods of negative daily difference between CDI and the threshold need to be established. To this end, monthly periods of the lowest CDI variety were found by applying a 22-day moving average window to the number of days with negative deviations from the threshold. Threshold 2 was defined as 80 percent of lowest variety days within each 22-day moving window, i.e., during each 22-day period there should be at least 18 days with the lowest variety of the CDI.

The application of these two thresholds allowed finding the episodes of the exchange rate network stationarity. During 2005-2016, there were four periods when the network was stationary and therefore all bilateral exchange rates could be considered in a relative multilateral equilibrium: June-July 2007, end-November to December 2013, February 2014, and end-April to early September 2014 (Figure 3). In addition, the CDI appropriately captures the period of the 2008-2009 financial crisis, where increased temporal volatility and sectional variety suggested highly hectic movements in CDI and an extreme instability of the exchange rate network.

Finally, the episodes of the multilateral exchange rate network stationarity allow identifying the equilibrium bilateral exchange rates. These levels can be considered the multilateral equilibrium exchange rates as they prevailed during the episodes when the network as a whole was in a stationary position (Table 2). This stationarity of the network reflects a fundamental, although temporary, equilibrium of all balance of payments flows in all currencies simultaneously. Therefore, each bilateral exchange rate can be considered in equilibrium only conditional on the level of all other bilateral exchange rates during the same episode. For example, during the 2007 episode, the USD /EUR $=0.74$ can be viewed as the equilibrium, only if USD $/ \mathrm{JPY}=122.39$ and $\mathrm{USD} / \mathrm{GBP}=0.50$. The multilateral equilibrium is different in the 2014 exchange rate network stationarity episode: the equilibrium exchange rate between EUR and USD was still the same, 


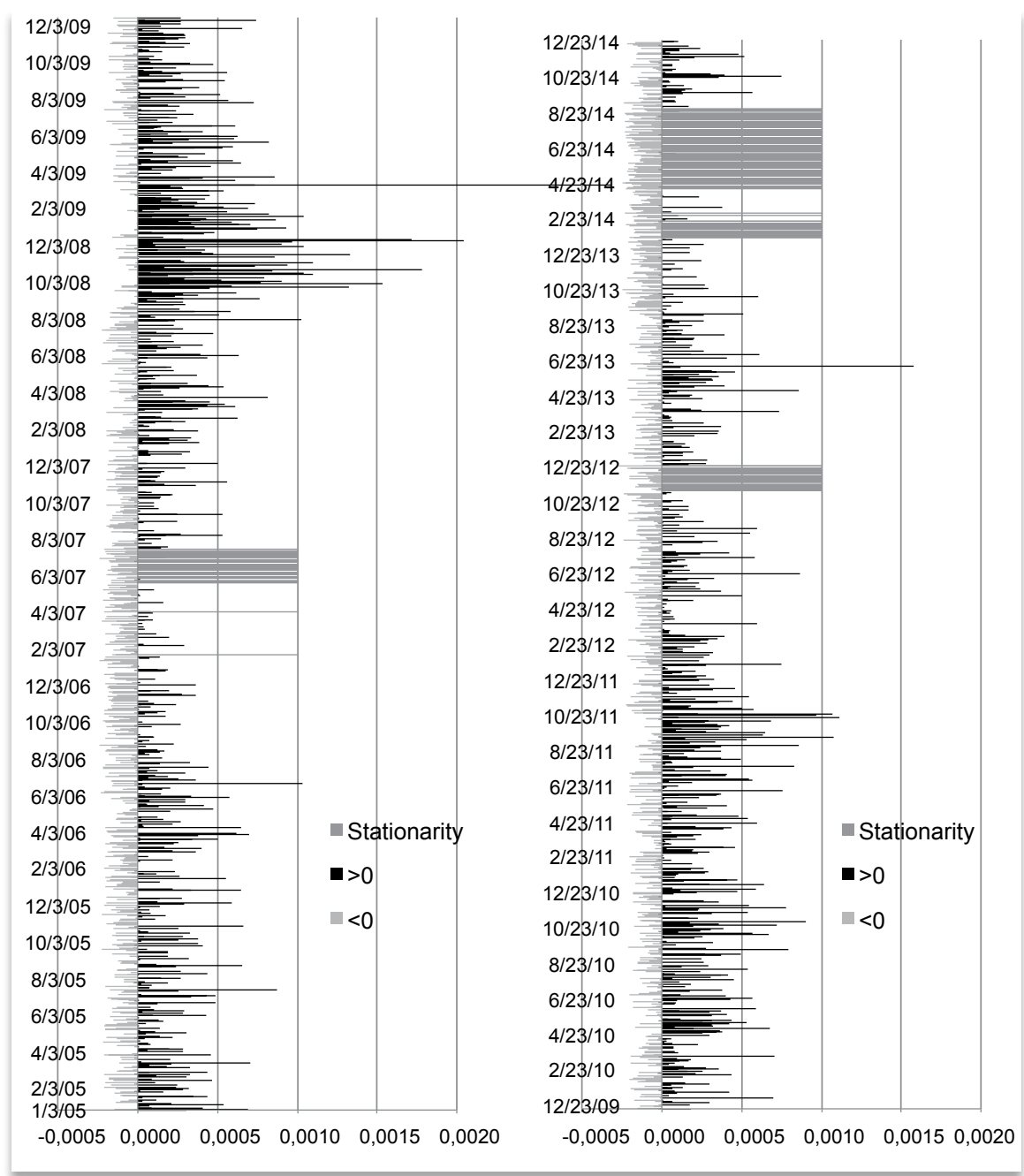

Figure 3

Episodes of multilateral exchange rate stationarity (Sectional variety, Currency demand indicator)

Source: authors' estimates.

$\mathrm{USD} / \mathrm{EUR}=0.74$. However, it was part of the multilateral equilibrium only if USD/JPY 102.28 and USD / GBP $=0.59$, and other exchange rates at the level to USD indicated in the Table 2.

The model can be used for policy-making in a four-step approach. Analytical services of Central Banks should: first, build a network model of multilateral exchange rates along the lines described above; such a model should be updatable in real time and at the desired frequencies useful for policy making - monthly, weekly, daily; second, calculate the multilateral CDI in real time and assess its sectoral variety to detect the periods of its relative multilateral stationarity; third, calculate the deviations of current nomi- 
Table 2

Multilateral equilibrium exchange rates (Units of national currency per US Dollar)

\begin{tabular}{|c|c|c|c|c|c|}
\hline \multicolumn{2}{|l|}{ Episode dates } & $\begin{array}{l}5 / 29 / 2007 \\
7 / 24 / 2007\end{array}$ & $\begin{array}{c}11 / 19 / 2012 \\
1 / 1 / 2013\end{array}$ & $\begin{array}{l}1 / 27 / 2014 \\
2 / 25 / 2014\end{array}$ & $\begin{array}{l}4 / 21 / 2014 \\
9 / 5 / 2014\end{array}$ \\
\hline \multicolumn{2}{|l|}{ "Duration (working days) } & 41 & 32 & 22 & 100 \\
\hline EURO & EUR & 0.74 & 0.77 & 0.73 & 0.74 \\
\hline JAPANESE YEN & JPY & 122.39 & 83.36 & 102.14 & 102.28 \\
\hline SWISS FRANC & CHF & 1.22 & 0.92 & 0.90 & 0.90 \\
\hline RUSSIAN ROUBLE & RUB & 25.75 & 30.83 & 35.15 & 35.19 \\
\hline CHINESE YUAN & CNY & 7.61 & 6.23 & 6.07 & 6.21 \\
\hline CANADIAN DOLLAR & CAD & 1.06 & 0.99 & 1.11 & 1.09 \\
\hline INDIAN RUPEE & INR & 40.63 & 54.85 & 62.38 & 60.09 \\
\hline BRAZILIAN REAL & BRL & 1.91 & 2.08 & 2.40 & 2.24 \\
\hline AUSTRALIAN DOLLAR & AUD & 1.17 & 0.96 & 1.12 & 1.07 \\
\hline SOUTH AFRICA RAND & ZAR & 7.07 & 8.69 & 11.03 & 10.61 \\
\hline MEXICAN PESO & MXN & 10.81 & 12.91 & 13.31 & 13.02 \\
\hline SOUTH KOREAN WON & KRW & 924.03 & $1,078.52$ & $1,072.41$ & $1,023.28$ \\
\hline NORWEGIAN KRONE & NOK & 5.91 & 5.63 & 6.14 & 6.09 \\
\hline SWEDISH KRONA & SEK & 6.84 & 6.62 & 6.49 & 6.75 \\
\hline INDONESIAN RUPIAH & IDR & $9,002.21$ & $9,629.00$ & $12,021.43$ & $11,685.97$ \\
\hline UK POUND & GBP & 0.50 & 0.62 & 0.60 & 0.59 \\
\hline
\end{tabular}

Source: Authors' estimates; Thomson Reuters Datastream.

nal exchange rates from their multilateral equilibrium levels based on nominal bilateral exchange rate levels observed during the period of recent CDI stationarity; and finally, take policy measures (monetary, fiscal, exchange rate, structural) to close the gap between current bilateral exchange rates and their multilateral equilibrium levels.

\section{Conclusions}

The network model of exchange rates allows the identification of the multilateral equilibrium levels of bilateral exchange rates. This approach requires the construction of an exchange rate network based on the multilateral currency demand indicator (CDI). The indicator reflects weighted demand for each currency from all other currencies in the network. It also implicitly reflects all underlying balance of payments flows denominated in different currencies. The weighted nature of the CDI allows studying the evolution of the role of individual currencies and the balance of payments flows in these currencies. Timely detection and prediction of the episodes of the multilateral exchange rate network stationarity and non-stationarity may be useful for policymakers for ensuring exchange rate stability in the periods of increased temporal variety of exchange rates. 
The model has a number of important limitations. First, the CDI is more likely to capture stability in reserve currencies, rather than stability across all currencies in the sample. The weights used in the analysis rely heavily on the share of currencies in the international currency turnover. The weights exhibit fat tails in the sense that reserve currencies dominate global foreign exchange markets. Second, the CDI has to rely on incomplete triennial data sources, such as BIS. Therefore, the adjacency matrix that yields the weights on bilateral flows is remarkably sparse. For example, the adjacency matrix suggests that the currencies of U.K. and Japan have no links, as the currency weight is missing from the BIS and may be misspecified. Third, the model rests on some strong assumptions, such as the balance of demand and supply of currencies being delinked from countries of their issuances. However, countries issuing reserve currencies may often affect them via their monetary and exchange rate policies. For example, the normalization of U.S. monetary policy and monetary policy divergence among countries issuing reserve currencies is likely to have an impact on the CDI.

Possible extensions of the model may make it more useful for policy advice. They include further exploration of the CDI, its properties and dynamics. Additional studies of the exchange rate network and its early warning properties would allow the signaling of the switching between its stationary and non-stationary regimes and may be important predictors of currency crises. Additional exploration of the multilateral equilibrium bilateral exchange rates could allow researchers to assess their current levels relative to the new metric of the multilateral network equilibrium. Finally, the calculations of the observed bilateral exchange rates deviations from their multilateral stationary levels would signal their overvaluation or undervaluation, which could become an important input for the policy dialogue with IMF member countries.

\section{ANNEX}

Table A1

Currency acronyms list

\begin{tabular}{|l|l|l|l|l|l|}
\hline Ticker & Currency & Ticker & Currency & Ticker & Currency \\
\hline \hline AED & UAE DIRHAM & GNF & GUINEA FRANC & PEN & PERUVIAN NUEVO SOL \\
\hline ALL & ALBANIAN LEK & GTQ & GUATEMALA QUETZAL & PGK & NEW GUINEA KINA \\
\hline AOA & ANGOLAN KWANZA & HKD & HONG KONG DOLLAR & PHP & PHILIPPINE PESO \\
\hline ARS & ARGENTINE PESO & HNL & HONDURAS LEMPIRA & PKR & PAKISTAN RUPEE \\
\hline AUD & AUSTRALIAN DOLLAR & HRK & CROATIAN KUNA & PLN & POLISH ZLOTY \\
\hline AWG & ARUBAN FLORIN & HTG & HAITIAN GOURDE & PYG & PARAGUAY GUARANI \\
\hline AZN & NEW AZERBAIJAN MANAT & HUF & HUNGARIAN FORINT & QAR & QATARI RIAL \\
\hline BAM & BOSNIA HERCEGOVINIAN & IDR & INDONESIAN RUPIAH & RON & NEW ROMANIAN LEU \\
\hline BBD & BARBADOS DOLLAR & ILS & ISRAELI SHEKEL & RSD & SERBIAN DINAR \\
\hline BDT & BANGLADESH TAKA & INR & INDIAN RUPEE & RUB & RUSSIAN ROUBLE \\
\hline
\end{tabular}


End of Table A1

\begin{tabular}{|c|c|c|c|c|c|}
\hline Ticker & Currency & Ticker & Currency & Ticker & Currency \\
\hline BGN & BULGARIAN LEV & ISK & ICELANDIC KRONA & RWF & RWANDA FRANC \\
\hline BHD & BAHRAINI DINAR & JMD & JAMAICAN DOLLAR & SAR & SAUDI RIYAL \\
\hline $\mathrm{BIF}$ & BURUNDI FRANC & JOD & JORDANIAN DINAR & SBD & SOLOMON ISLANDS \\
\hline BMD & BERMUDA DOLLAR & JPY & JAPANESE YEN & SCR & SEYCHELLES RUPEE \\
\hline BND & BRUNEI DOLLAR & KES & KENYAN SHILLING & SEK & SWEDISH KRONA \\
\hline ВOB & BOLIVIAN BOLIVIANO & KGS & KYRGYZ SOM & SGD & SINGAPORE DOLLAR \\
\hline BRL & BRAZILIAN REAL & KMF & COMORAN FRANC & SLL & SIERRA LEONE LEONE \\
\hline BSD & BAHAMAS DOLLAR & KRW & SOUTH KOREAN WON & SRD & SURINAME DOLLAR \\
\hline BTN & BHUTAN NGULTRUM & KWD & KUWAITI DINAR & SVC & EL SALVADOR COLON \\
\hline BWP & BOTSWANAN PULA & KZT & KAZAKHSTAN TENGE & SZL & SWAZILAND LILANGENI \\
\hline BYR & BELARUS ROUBLE & LBP & LEBANESE POUND & THB & THAI BAHT \\
\hline CAD & CANADIAN DOLLAR & LKR & SRI LANKAN RUPEE & THO & THAI BAHT OFFSHORE \\
\hline $\mathrm{CDF}$ & CONGO (DRC) FRANC & LSL & LESOTHO LOTI & TND & TUNISIAN DINAR \\
\hline $\mathrm{CHF}$ & SWISS FRANC & MAD & MOROCCAN DIRHAM & TOP & TONGAN PA'ANGA \\
\hline CLP & CHILEAN PESO & MDL & MOLDOVAN LEU & TRY & NEW TURKISH LIRA \\
\hline $\mathrm{CNH}$ & CHINESE YUAN HK CNH & MGA & MALAGASY ARIARY & TTD & TRINIDAD AND TOBAGO DOLLAR \\
\hline $\mathrm{CNY}$ & CHINESE YUAN & MKD & MACEDONIAN DENAR & TWD & TAIWAN NEW DOLLAR \\
\hline $\mathrm{COP}$ & COLOMBIAN PESO & MNT & MONGOLIAN TUGRIK & TZS & TANZANIAN SHILLING \\
\hline CRC & COSTA RICAN COLON & MOP & MACAO PATACA & UAH & UKRAINE HRYVNIA \\
\hline CUP & CUBAN PESO & MRO & MAURITANIAN OUGUYIA & UGX & UGANDA NEW SHILLING \\
\hline CVE & PORTUGUESE ESCUDO & MUR & MAURITIUS RUPEE & USD & USA DOLLAR \\
\hline CZK & CZECH KORUNA & MVR & MALDIVE ISLAND RUFIY & UYI & URUGUAYAN PESO \\
\hline DKK & DANISH KRONE & MWK & MALAWIAN KWACHA & UZS & UZBEKISTAN SUM COUP \\
\hline DOP & DOMINICAN REP. PESO & MXN & MEXICAN PESO & VEF & VENEZ. BOLIVAR \\
\hline DZD & ALGERIAN DINAR & MYR & MALAYSIAN RINGGIT & VND & VIETNAMESE DONG \\
\hline EGP & EGYPTIAN POUND & MZN & $\begin{array}{l}\text { NEW MOZAMBIQ } \\
\text { METICAL }\end{array}$ & VUV & VANUATU VATU \\
\hline ETB & ETHIOPIAN BIRR & NGN & NIGERIAN NAIRA & WST & SAMOAN TALA \\
\hline EUR & EURO & NIO & NICARAGUAN CORDOBA & XCD & ANTIGUAN EAST CARIBB \\
\hline FJD & FIJIAN DOLLAR & NOK & NORWEGIAN KRONE & $\mathrm{XOF}$ & CFA FRANC BENIN \\
\hline GBP & UK POUND & NPR & NEPALESE RUPEE & XPF & FRENCH PACIFIC CFP FRANC \\
\hline GEL & GEORGIAN LARI & NZD & NEW ZEALAND DOLLAR & $\mathrm{XSU}$ & ECUADOR SUCRE \\
\hline GHS & GHANAIAN CEDI & OMR & OMAN RIAL & YER & YEMEN RIAL \\
\hline GMD & GAMBIAN DALASI & $\mathrm{PAB}$ & PANAMA BALBOA & ZAR & SOUTH AFRICA RAND \\
\hline GNF & GUINEA FRANC & & & ZMW & ZAMBIAN KWACHA \\
\hline
\end{tabular}

Source: BIS, 2013. 
Table A2

Global foreign exchange market turnover by currency pair (on a net basis, daily averages in April, in billions of US dollars and percentages)

\begin{tabular}{|c|c|c|c|c|c|c|c|c|c|c|}
\hline \multirow{2}{*}{ Currency pair } & \multicolumn{2}{|c|}{2001} & \multicolumn{2}{|c|}{2004} & \multicolumn{2}{|c|}{2007} & \multicolumn{2}{|c|}{2010} & \multicolumn{2}{|c|}{2013} \\
\hline & Amount & $\%$ & Amount & $\%$ & Amount & $\%$ & Amount & $\%$ & Amount & $\%$ \\
\hline USD / EUR & 372 & 30.0 & 541 & 28.0 & 892 & 26.8 & 1,098 & 27.7 & 1,289 & 24.1 \\
\hline USD / JPY & 250 & 20.2 & 328 & 17.0 & 438 & 13.2 & 567 & 14.3 & 978 & 18.3 \\
\hline USD / GBP & 129 & 10.4 & 259 & 13.4 & 384 & 11.6 & 360 & 9.1 & 472 & 8.8 \\
\hline USD / AUD & 51 & 4.1 & 107 & 5.5 & 185 & 5.6 & 248 & 6.3 & 364 & 6.8 \\
\hline USD / CAD & 54 & 4.3 & 77 & 4.0 & 126 & 3.8 & 182 & 4.6 & 200 & 3.7 \\
\hline USD / CHF & 59 & 4.8 & 83 & 4.3 & 151 & 4.5 & 166 & 4.2 & 184 & 3.4 \\
\hline USD / MXN & $\ldots$ & $\ldots$ & $\ldots$ & $\ldots$ & $\ldots$ & $\ldots$ & $\ldots$ & $\ldots$ & 128 & 2.4 \\
\hline USD / CNY & $\ldots$ & $\ldots$ & $\ldots$ & $\ldots$ & $\ldots$ & $\ldots$ & 31 & 0.8 & 113 & 2.1 \\
\hline USD / NZD & $\ldots$ & $\ldots$ & $\ldots$ & $\ldots$ & $\ldots$ & $\ldots$ & $\ldots$ & $\ldots$ & 82 & 1.5 \\
\hline USD / RUB & $\ldots$ & $\ldots$ & $\ldots$ & $\ldots$ & $\ldots$ & $\ldots$ & $\ldots$ & $\ldots$ & 79 & 1.5 \\
\hline USD / HKD & $\ldots$ & $\ldots$ & $\ldots$ & $\ldots$ & $\ldots$ & $\ldots$ & 85 & 2.1 & 69 & 1.3 \\
\hline USD / SGD & $\ldots$ & $\ldots$ & $\ldots$ & $\cdots$ & $\ldots$ & $\ldots$ & $\ldots$ & $\ldots$ & 65 & 1.2 \\
\hline USD / TRY & $\ldots$ & $\ldots$ & $\ldots$ & $\ldots$ & $\ldots$ & $\ldots$ & $\ldots$ & $\ldots$ & 63 & 1.2 \\
\hline USD / KRW & $\ldots$ & $\ldots$ & $\ldots$ & $\ldots$ & $\ldots$ & $\ldots$ & 58 & 1.5 & 60 & 1.1 \\
\hline USD / SEK & $\ldots$ & $\ldots$ & $\ldots$ & $\ldots$ & 57 & 1.7 & 45 & 1.1 & 55 & 1.0 \\
\hline USD / ZAR & $\ldots$ & $\ldots$ & $\ldots$ & $\ldots$ & $\ldots$ & $\ldots$ & 24 & 0.6 & 51 & 1.0 \\
\hline USD / INR & $\ldots$ & $\ldots$ & $\ldots$ & $\ldots$ & $\ldots$ & $\ldots$ & 36 & 0.9 & 50 & 0.9 \\
\hline USD / NOK & $\ldots$ & $\ldots$ & $\ldots$ & $\ldots$ & $\ldots$ & $\ldots$ & $\ldots$ & $\ldots$ & 48 & 0.9 \\
\hline USD / BRL & $\ldots$ & $\ldots$ & $\ldots$ & $\ldots$ & $\ldots$ & $\ldots$ & 25 & 0.6 & 48 & 0.9 \\
\hline USD / PLN & $\ldots$ & $\ldots$ & $\ldots$ & $\ldots$ & $\ldots$ & $\ldots$ & $\ldots$ & $\ldots$ & 22 & 0.4 \\
\hline USD / TWD & $\ldots$ & $\ldots$ & $\ldots$ & $\ldots$ & $\ldots$ & $\ldots$ & $\ldots$ & $\ldots$ & 22 & 0.4 \\
\hline USD / OTH & 199 & 16.0 & 307 & 15.9 & 612 & 18.4 & 445 & 11.2 & 213 & 4.0 \\
\hline EUR / JPY & 36 & 2.9 & 61 & 3.2 & 86 & 2.6 & 111 & 2.8 & 147 & 2.8 \\
\hline EUR / GBP & 27 & 2.1 & 47 & 2.4 & 69 & 2.1 & 109 & 2.7 & 102 & 1.9 \\
\hline EUR / CHF & 13 & 1.1 & 30 & 1.6 & 62 & 1.9 & 71 & 1.8 & 71 & 1.3 \\
\hline EUR / SEK & $\cdots$ & $\cdots$ & $\ldots$ & $\ldots$ & 24 & 0.7 & 35 & 0.9 & 28 & 0.5 \\
\hline EUR / AUD & 1 & 0.1 & 4 & 0.2 & 9 & 0.3 & 12 & 0.3 & 21 & 0.4 \\
\hline EUR / NOK & $\ldots$ & $\ldots$ & $\ldots$ & $\ldots$ & $\ldots$ & $\ldots$ & $\ldots$ & $\ldots$ & 20 & 0.4 \\
\hline EUR / CAD & 1 & 0.1 & 2 & 0.1 & 7 & 0.2 & 14 & 0.3 & 15 & 0.3 \\
\hline EUR / PLN & $\cdots$ & $\cdots$ & $\cdots$ & $\cdots$ & $\ldots$ & $\ldots$ & $\ldots$ & $\ldots$ & 14 & 0.3 \\
\hline EUR / DKK & $\ldots$ & $\ldots$ & $\ldots$ & $\ldots$ & $\ldots$ & $\ldots$ & $\ldots$ & $\ldots$ & 13 & 0.2 \\
\hline EUR / HUF & $\ldots$ & $\ldots$ & $\ldots$ & $\ldots$ & $\ldots$ & $\ldots$ & $\ldots$ & $\ldots$ & 9 & 0.2 \\
\hline EUR / TRY & $\ldots$ & $\ldots$ & $\ldots$ & $\ldots$ & $\ldots$ & $\ldots$ & $\ldots$ & $\ldots$ & 6 & 0.1 \\
\hline EUR / CNY & $\ldots$ & $\cdots$ & $\ldots$ & $\ldots$ & $\ldots$ & $\ldots$ & $\ldots$ & $\ldots$ & 1 & 0.0 \\
\hline EUR / OTH & 20 & 1.6 & 38 & 1.9 & 83 & 2.5 & 102 & 2.6 & 52 & 1.0 \\
\hline JPY / AUD & $\cdots$ & $\ldots$ & $\ldots$ & $\ldots$ & $\ldots$ & $\ldots$ & 24 & 0.6 & 45 & 0.8 \\
\hline
\end{tabular}


End of Table A2

\begin{tabular}{|l|c|c|c|c|c|c|c|c|c|c|}
\hline \multirow{2}{*}{ Currency pair } & \multicolumn{2}{|c|}{2001} & \multicolumn{2}{c|}{2004} & \multicolumn{2}{c|}{2007} & \multicolumn{2}{c|}{2010} & \multicolumn{2}{c|}{2013} \\
\cline { 2 - 13 } & Amount & $\%$ & Amount & $\%$ & Amount & $\%$ & Amount & $\%$ & Amount & $\%$ \\
\hline \hline JPY / CAD & $\ldots$ & $\ldots$ & $\ldots$ & $\ldots$ & $\ldots$ & $\ldots$ & $\ldots$ & $\ldots$ & 6 & 0.1 \\
\hline JPY / NZD & $\ldots$ & $\ldots$ & $\ldots$ & $\ldots$ & $\ldots$ & $\ldots$ & 4 & 0.1 & 5 & 0.1 \\
\hline JPY / ZAR & $\ldots$ & $\ldots$ & $\ldots$ & $\ldots$ & $\ldots$ & $\ldots$ & $\ldots$ & $\ldots$ & 4 & 0.1 \\
\hline JPY / BRL & $\ldots$ & $\ldots$ & $\ldots$ & $\ldots$ & $\ldots$ & $\ldots$ & $\ldots$ & $\ldots$ & 3 & 0.1 \\
\hline JPY / TRY & $\ldots$ & $\ldots$ & $\ldots$ & $\ldots$ & $\ldots$ & $\ldots$ & $\ldots$ & $\ldots$ & 1 & 0.0 \\
\hline JPY / OTH & 5 & 0.4 & 14 & 0.7 & 49 & 1.5 & 49 & 1.2 & 42 & 0.8 \\
\hline $\begin{array}{l}\text { Other currency } \\
\text { pairs }\end{array}$ & 23 & 1.8 & 36 & 1.9 & 90 & 2.7 & 72 & 1.8 & 89 & 1.7 \\
\hline $\begin{array}{l}\text { All currency } \\
\text { pairs }\end{array}$ & 1,239 & 100 & 1,934 & 100.0 & 3,324 & 100.0 & 3,971 & 100.0 & 5,345 & 100.0 \\
\hline $\begin{array}{l}1 \\
\text { Adjusted for local and cross-border inter-dealer double-counting (ie “net-net" basis). }\end{array}$ \\
\hline
\end{tabular}

Source: BIS, 2013.

REFERENCES (with English translation or transliteration)

Acemoglu D., Akcigit U., Kerr W. (2015). Networks and the Macroeconomy: An Empirical Exploration. NBER Working Paper No. 21344. National Bureau of Economic Research.

BIS (2013). Triennial Central Bank Survey of Foreign Exchange and Derivatives Market Activity in 2013. Available at: www.bis.org (accessed: December 2018).

Bouchaud J.P., Potters M. (2003). Theory of Financial Risk and Derivative Pricing: from Statistical Physics to Risk Management. Cambridge: Cambridge University Press.

Brooks C. (2014). Introductory Econometrics for Finance. Cambridge: Cambridge University Press.

Caschili S., Medda F.R., Wilson A. (2015). An Interdependent Multi-Layer Model: Resilience of International Networks. Networks and Spatial Economics, $1-23$.

Fracasso A., Schiavo S. (2009). Global Imbalances, Exchange Rates Adjustment and the Crisis: Implications from Network Analysis. Journal of Policy Modeling, 31 (5), 601-619.

Heiberger R.H. (2014). Stock Network Stability in Times of Crisis. Physica A: Statistical Mechanics and Its Applications, 393, 376-381.

IMF (2015). Guidance Note for Surveillance under Article IV. Consultation. International Monetary Fund. Available at: www.imf.org/external/np/pp/ eng/2015/031915.pdf (accessed: December2018).

Kireyev A., Leonidov A. (2015). Network Effects of International Shocks and Spillovers. IMF Working Papers 15/149. International Monetary Fund.

Kireyev A., Leonidov A. (2016). China's Imports Slowdown: Spillovers, Spillins and Spillback. IMF Working Papers 16/51. International Monetary Fund. 
Kivelä M., Arenas A., Barthelemy M., Gleeson J.P., Moreno Y., Porter M.A. (2014). Multilayer Networks. Journal of Complex Networks, 2 (3), 203-271.

Krings G., Carpantier J.-F., Delvenne J.-C. (2014). Trade Integration and Trade Imbalances in the European Union: a Network Perspective. Plos One, 9 (1). Available at: https://doi.org/10.1371/journal.pone.0083448 (accessed: December 2018).

Kwapień J., Gworek S., Drożdż, S., Górski A. (2009). Analysis of a Network Structure of the Foreign Currency Exchange Market. Journal of Economic Interaction and Coordination, 4 (1), 55-72.

Matesanz D., Ortega G.J. (2014). Network Analysis of Exchange Data:Interdependence Drives Crisis Contagion. Quality $\mathcal{E}$ Quantity, 48 (4), 1835-1851.

Qiao H., Li Y., Xia Y. (2015). Analysis of Linkage Effects among Currency Networks Using REER Data. Discrete Dynamics in Nature and Society.

Phillips M.S., Catão M.L., Ricci M.L.A., Bems R., Das M., Di G., Vargas J.M. (2013). The External Balance Assessment (EBA) Methodology. IMF Working Paper No. 13/272. International Monetary Fund.

Serrano M.Á., Boguñá M., Vespignani A. (2007). Patterns of Dominant Flows in the World Trade Web. Journal of Economic Interaction and Coordination, 2 (2), 111-124.

Sinha S., Kovur U. (2014). Uncovering the Network Structure of the World Currency Market: Cross-Correlations in the Fluctuations of Daily Exchange Rates. In: "Econophysics of Agent-Based Models". Springer International Publishing, 203-218.

Squartini T., Garlaschelli D. (2014). Stationarity, Non-Stationarity and Early Warning Signals in Economic Networks. Journal of Complex Networks, May, 1-25.

Sornette D. (2002). Predictability of Catastrophic Events: Material Rupture, Earthquakes, Turbulence, Financial Crashes, and Human Birth. Proceedings of the National Academy of Sciences, 99 (suppl. 1), 2522-2529.

Received 27.07.2018

\section{ЛИТЕРАТУРА}

Acemoglu D., Akcigit U., Kerr W. (2015). Networks and the Macroeconomy: An Empirical Exploration. NBER Working Paper No. 21344. National Bureau of Economic Research.

BIS (2013). Triennial Central Bank Survey of Foreign Exchange and Derivatives Market Activity in 2013. [Электронный ресурс] Режим доступа: www.bis.org, свободный. Загл. с экрана. Яз. англ. (дата обращения: декабрь 2018 г.).

Bouchaud J.P., Potters M. (2003). Theory of Financial Risk and Derivative Pricing: from Statistical Physics to Risk Management. Cambridge: Cambridge University Press.

Brooks C. (2014). Introductory Econometrics for Finance. Cambridge: Cambridge University Press. 
Caschili S., Medda F.R., Wilson A. (2015). An Interdependent Multi-Layer Model: Resilience of International Networks. Networks and Spatial Economics. P. 1-23.

Fracasso A., Schiavo S. (2009). Global Imbalances, Exchange Rates Adjustment and the Crisis: Implications from Network Analysis / / Journal of Policy Modeling. Vol. 31 (5). P. 601-619.

Heiberger R.H. (2014). Stock Network Stability in Times of Crisis // Physica A: Statistical Mechanics and Its Applications. Vol. 393. P. 376-381.

IMF (2015). Guidance Note for Surveillance under Article IV. Consultation. [Электронный ресурс] International Monetary Fund. Режим доступа: www.imf.org/external/np/pp/eng/2015/031915.pdf, свободный. Загл. с экрана. Яз. англ. (дата обращения: декабрь 2018 г.).

Kireyev A., Leonidov A. (2015). Network Effects of International Shocks and Spillovers. IMF Working Papers 15/149. International Monetary Fund.

Kireyev A., Leonidov A. (2016). China's Imports Slowdown: Spillovers, Spillins and Spillback. IMF Working Papers 16/51. International Monetary Fund.

Kivelä M., Arenas A., Barthelemy M., Gleeson J.P., Moreno Y., Porter M.A. (2014). Multilayer Networks / / Journal of Complex Networks. Vol. 2 (3). P. 203-271.

Krings G., Carpantier J.-F., Delvenne J.-C. (2014). Trade Integration and Trade Imbalances in the European Union: a Network Perspective // Plos One. Vol. 9 (1). Available at: https://doi.org/10.1371/journal.pone.0083448 (accessed: December 2018).

Kwapień J., Gworek S., Drożdż, S., Górski A. (2009). Analysis of a Network Structure of the Foreign Currency Exchange Market / / Journal of Economic Interaction and Coordination. Vol. 4 (1). P. 55-72.

Matesanz D., Ortega G.J. (2014). Network Analysis of Exchange Data: Interdependence Drives Crisis Contagion / / Quality E Quantity. Vol. 48 (4). P. 1835-1851.

Qiao H., Li Y., Xia Y. (2015). Analysis of Linkage Effects among Currency Networks Using REER Data. Discrete Dynamics in Nature and Society.

Phillips M.S., Catão M.L., Ricci M.L.A., Bems R., Das M., Di G., Vargas J.M. (2013). The External Balance Assessment (EBA) Methodology. IMF Working Paper No. 13/272. International Monetary Fund.

Serrano M.Á., Boguñá M., Vespignani A. (2007). Patterns of Dominant Flows in the World Trade Web // Journal of Economic Interaction and Coordination. Vol. 2 (2). P. 111-124.

Sinha S., Kovur U. (2014). Uncovering the Network Structure of the World Currency Market: Cross-correlations in the Fluctuations of Daily Exchange Rates. In: "Econophysics of Agent-Based Models". Springer International Publishing. P. 203-218.

Squartini T., Garlaschelli D. (2014). Stationarity, Non-Stationarity and Early Warning Signals in Economic Networks / / Journal of Complex Networks, May. P. 1-25.

Sornette D. (2002). Predictability of Catastrophic Events: Material Rupture, Earthquakes, Turbulence, Financial Crashes, and Human Birth / / Proceedings of the National Academy of Sciences. Vol. 99 (suppl. 1). P. 2522-2529.

Received 27.07.2018 


\section{А.П. Киреев}

Международный валютный фонд, Вашингтон, США;

Московская школа экономики, Москва, Россия

\section{А.В. Леонидов}

Физический институт имени П.Н. Лебедева, Российская академия наук (РАН); Московский физико-технический институт (государственный университет), Москва, Россия

\section{Сетевая модель многосторонних равновесных валютных курсов}

Аннотация. Статья предлагает модель многосторонних равновесных обменных курсов, основанную на теории сетей. Модель вводит топологический компонент в анализ обменного курса, последовательно включая взаимодействия более высокого порядка между всеми валютами одновременно. В статье показывается, что эволюция номинальных обменных курсов может быть смоделирована на сети, где узлы представляют отдельные валюты, а связи между ними представляют взвешенную прибыль на гипотетические инвестиции в каждую валюту. Многосторонняя сеть обменных курсов представлена многосторонне зависимыми изменениями в двусторонних обменных курсах. Индикатор спроса на валюту (CDI), элементарная ячейка сетевой модели, определяется как взвешенный лог-доход по каждой валюте. CDI предоставляет полезный прокси для спроса на каждую валюту со стороны других валют и отражает все основные потоки платежного баланса. Модель идентифицирует стационарное положение сети обменных курсов, то есть эпизоды минимального временного разнообразия CDI, когда взвешенные доходы по связям между узлами близки к нулю. Стационарное положение сети обменных курсов указывает на равновесный уровень двусторонних обменных курсов для каждой валютной пары. Модель применима в основном к валютам с режимами плавающего обменного курса, хотя полезную информацию можно также получить для валют с фиксированными обменными курсами. В качестве иллюстрации модель применяется к двусторонним ежедневным обменным курсам 1995-2016 гг. между 130 валютами, полученными из потока данных Thomson Reuters.

Ключевые слова: обменный курс, сети, равновесие, торговля.

Классификация JEL: C45, F14, F41, F42, F47.

DOI: $10.31737 / 2221-2264-2019-41-1-1$ 